\title{
The (d)evolution of scientific temper in India
}

\author{
K. Lalchhandama \\ President, Mizo Academy of Sciences, Sikulpuikawn, Aizawl 796ooI, India
}

\begin{abstract}
Jawaharlal Nehru was most instrumental in instilling scientific temper at the birth of modern India. In contrast, as Bharatiya Janata Party came into power in 2014, their top-down governance is explicitly trying to promote Vedic science. The Prime Minister boasted off of genetics in Mahabharata, and plastic surgery in the Vedas. The origin of Heisenberg's uncertainty principle form the Vedas is the pride of the Home Minister. The Minister of Science and Technology contended that the Vedas contain better theory than $\mathrm{E}=\mathrm{mc}^{2}$. There is increased veneration of cattle. A large-scale promotion of bovine urine and dung as medicine, called cowpathy or, as they embrace it, panchagavya is on the rise. To that effect, gold was discovered in the urine of Gir cows, but really to no effect. Their cows breathe in and out oxygen, and peafowl are confirmed celibates. The Minister of State for Human Resources Development ridiculed evolutionary biology proclaiming that Darwin's theory is scientifically flawed. We, the people of India, deserve better wisdom. As Nehru would have put it, "a baseless dogma or a hopeless aspiration" of this sort will never elate India, or any nation for that matter, to scientific progression, not to say economic and social developments.
\end{abstract}

\section{Introduction}

It shall be the duty of every citizen of India

h) to develop the scientific temper, humanism and the spirit of inquiry and reform.

- The Constitution of India 1949 Article 51A. Fundamental Duties.

While (most of) the rest of the world is more and more advancing towards rationalismscience and secularism are growing by leaps and bound-India has the leadership of Bharatiya Janata Party (BJP), which has revealed its fair share of ideology in which science basically equates stupidity. But from the time that this government was elected to office in 2014, a number of outrageous and farcical claims have been expressed by leaders of the party, including the Prime Minister. He and his party has risen to the inglorious height of scientific incredulity, and consistently managed to put their feet in their mouths with despicable displays of ignorance and irrationality. Their ploy to propagate Hindu ideologies is no secret-beef ban and yoga would give away. For the dyed-in-the-wool Hindutva, BJP and its trusted confidant Rashtriya Swayamsevak Sangh (RSS), it looks as if it is the fundamental duty to foist ancient Hindu myths as roots of modern science, which it is not.

Antiquated, incredulous and atrocious claims coming from the leadership of BJP are at the very peril of what science is now today-an objective 
knowledge built on the (dynamic) rock of verifiability and falsifiability. Sometimes we are left wondering whether to laugh or cry to such absurd and contemptible outbursts of nonsense and nonscience. BJP ministers and scholar take the Indian Science Congress as an opportune platform for spreading their appalling antiscientific views. If they go on like this, science and science education will plummet into the abyss of total ignorance. It is in a spur of the moment like this, I feel it as the time when stones have to cry out-I am merely a disgruntled pebble, though. I could not have put it better myself than quoting Charles Darwin (in his letter to T.H. Huxley, 9 July 1857): Alas! A scientific man ought to have no wishes, no affections-a mere heart of stone.

As India was unshackled from the colonial yoke of the British Empire, Indian elite thinkers took great pains establishing of allencompassing administration and constitution to unite a diverse culture. A scientist by learning, a lawyer by practice, and a politician by fame, Jawaharlal Nehru was one of the most instrumental leaders in shaping free India. He dared to make a rather bold confession in his book The Discovery of India, saying, "I was still less interested [than in historyl in the supernatural or problems of a future life. Science and the problems of to-day and of our present life attracted me far more." In talking about Hinduism, he blamed it for the stagnant social and cultural advancement, attributing to it as the factor that "sunk [India] into a state of 'mummified' and 'crystallized' civilization." It is here that he introduced the importance of scientific temper in its very nascent form, expressing:

... I am quite sure that some elementary scientific training in physics and chemistry, and especially biology, as also in the application of science, is essential for all boys and girls. Only thus can they understand and fit into the modern world and develop, to some extent at least, the scientific temper. ${ }^{3}$

A little later, he further gave a proper definition, which most obviously is the basis of the
Indian Fundamental Duties Article 51A(h), stating:

It is the scientific approach, the adventurous and yet critical temper of science, the search for truth and new knowledge, the refusal to accept anything without testing and trial, the capacity to change previous conclusions in the face of new evidence, the reliance on observed fact and not on pre-conceived theory, the hard discipline of the mind-all this is necessary, not merely for the application of science but for life itself and the solution of its many problems. ${ }^{4}$

The chief architect of the Indian Constitution, B.R. Ambedkar, had little but thoughtprovoking words to say on science:

Religion as defined in the first proposition must be in accord with science... In other words, religion if it is to function, must be in accord with reason which is merely another name for science. $^{5}$

\section{Vedic Science - Whatever that is}

Hindu nationalists have long clung to the ineffable belief that many discoveries of modern science and technology were known in ancient India. For the first time in history, the Prime Minister of India has publicly endorsed these claims, maintaining that cosmetic surgery and genetics were known thousands of years ago. As evidences, Narendra Modi resorted to the warrior Karna from the Sanskrit epic Mahabharata and of the elephant-headed Hindu god Ganesha respectively. At the inauguration of a Mumbai hospital in October 2014, he spoke, "We can feel proud of what our country achieved in medical science at one point of time," to the amzement of doctors and other medical professional audience. "We all read about Karna in the Mahabharata. If we think a little more, we realise that the Mahabharata says Karna was not born from his mother's womb. This means that genetic science was present at that time. That is why Karna could be born outside his mother's womb," he elaborated, and continued, "We wor- 
ship Lord Ganesha. There must have been some plastic surgeon at that time who got an elephant's head on the body of a human being and began the practice of plastic surgery." ${ }^{\prime \prime}$

Modi also told schoolchildren in 2014 that climate change is not an environmental problem or a physical fact; it is, instead, a matter of human beings' perception to heat and cold, which changes over time. "Global warming," he explained on national television, "is just a state of mind."

Vijnana Bharati (VIBHA), the science wing of the RSS, is teaming up with the government to launch a massive digital campaign to "promote scientific research". The term "scientific research", though, appears to be a clever euphemism for the real purpose of the initiative. ${ }^{8}$ Number one statement on the Aims and Objectives of VIBHA runs: To champion the cause of Bharatiya Heritage with a harmonious synthesis of physical and spiritual sciences which nourish each other and flourish together." Spiritual science? Goodness gracious, no! Pigs, sorry cows, might fly.

Home Minister Rajnath Singh, formerly a physicist, claimed that the concept of quantum uncertainty, more popularly known as Heisenberg's uncertainty principle, drew upon the Vedas. Then the BJP President, Singh delivered a Presidential address at the BJP campaign in 2013, just before BJP came into power, said, "Heisenberg learnt the Uncertainty Principle from the philosophy of Veda of this country. Heisenberg came to India in 1929 and met Rabindranath Tagore." Crediting Tagore as the mediator of Vedic science to Werner Heisenberg. ${ }^{10}$ Even if we remain ever uncertain on whatever Tagore might have said about science, we are quite certain of this-Heisenberg published his uncertainty theory two years earlier, in $1927 .{ }^{11}$

Such audacity had encouraged Hindu gurus such as Baba Ramdev to propose in 2016 to set up of Vedic Education Board (VEB) in alignment with the Central Board of Secondary Education. Modi had called for a meeting on the matter in which S. C. Khuntia, then the School Education Secretary, objected to such private education board. News flushed and flashed reporting that Ramdev was urging the Human Resource Development ministry to approve the proposal. Amidst public criticism, HRD Minister Prakash Javadekar was compelled to deny any of such proposal, commenting, "At this moment, there is no (such) proposal," and when asked why it was pending, he replied, "Nothing gets stuck."12

Another BJP appointee has gone a step further claiming that ancient India had nuclear weapons. Y. Sudershan Rao, head of the Indian Council of Historical Research, said that the destructive weapons described in the Mahabharata were using atomic fission and/or fusion. He also claimed that stem cell research was done in India during Iron Age. In 2016, Virendra Singh, a BJP MP from Uttar Pradesh had claimed in the Lok Sabha session that a ritual burning of ghee and foodstuff in havans [ritual burning of food] would bring better rains. ${ }^{13}$ He said it has been "scientifically-established" that burning ghee produces $300 \%$ more oxygen..$^{14}$ But the $18^{\text {th }}$ century science had already established that combustion consumes $\mathrm{O}_{2}$; what a contrast.

Harsh Vardhan, Minister of Science and Technology, of Environment, Forest and Climate Change, and of Earth Sciences, is fondly called "Doctor Saab" for he is an MBBS and MS in ENT. Addressing the inaugural session of the Indian Science Congress in Imphal on 16 March 2018, he asserted that Stephen Hawking [who died two days earlier on $14 \mathrm{March}$ ] had acknowledged that the Vedas might have "offered a better theory" than the mass-energy equivalence, $\mathrm{E}=\mathrm{mc}^{2}$, of Albert Einstein's theory of special relativity. He said, "We recently lost a renowned scientist, cosmologist Stephen Hawking. He also emphatically said on record that our Vedas might have a theory which is superior to the Einstein's theory of $E=m^{2}$." Asked to disclose the source, Vardhan told reporters, "You find the source. He [Hawking] had on record said there is a possibility the Vedas have a better formula than the one given by Einstein. You also work a bit on this." The minister even asked reporters to reach him in Delhi if they failed to find the source. ${ }^{15}$

Reporters did further inquiry, not to the ministry office, but to Cambridge. "I am certain that 
he did NOT support the claims made by your minister that 'our Vedas might have a theory which is superior to Einstein's theory of $\mathrm{E}=\mathrm{mc}^{2}$,", said Malcolm Perry, a professor of theoretical physics at the University of Cambridge, who is on the governance panel of the Stephen Hawking Foundation. The president of the Royal Society, Venkatraman Ramakrishnan, was not impressed when Vardhan's assertion was laid before him. According to Ramakrishnan: "A better Stephen Hawking quote would be, "The greatest enemy of knowledge is not ignorance, but the illusion of knowledge'."'16

\section{A Wonder Drug that Keeps Us Wondering}

BJP India is obsessed with cattle through and through. While it is an undeniable fact that cow is an extremely valuable animal in the sense that it is our primary source of milk, biogas, and biofertilizer, but claiming it, specifically its dung and urine, as source of medicine is detestable. That which they call cowpathy is most promoted by Swaarnim Naturscience Limited which runs Jain's Cow Urine Therapy Health Clinic at Indore in Madhya Pradesh [see www.cowurine.com]. This clinic employs cow urine for curing a cohort of ailments one can imagine existing, including cough, dysmenorrhoea, migraine or headache, constipation, thyroid and skin diseases like eczema, ringworm, and itching, acne, cancer, heart diseases, musculoskeletal disorders, male sexual disorders, AIDS, diabetes mellitus, blood disorders, respiratory disorders, gastrointestinal disorders, endocrine disorders, gynaecological disorders, ophthalmic disorders, psychiatric disorders, urological disorders, asthma, kidney shrinkage, hepatic disorders, and the list goes on. ${ }^{17}$ Council of Scientific and Industrial Research (CSIR) even has two U.S. patents (numbers 6896907 and 6410059) in cow urine as booster for antiparasitic and anticancer drugs. ${ }^{18}$ In spite of its attractive scientific scene, the evidences are still lame without clinical trials. (See for example Jain et al., 2010.19)

Drinking of urine, be it of human or cow, has been familiar in different cultures for many diseases. As Jutta M. Loeffler noted: "There is, it seems, virtually nothing urine won't cure." ${ }^{\prime 20} \mathrm{~A}$ rational explanation for the use of human's or cow's urine is that urine provides readily available material out of bare necessity in poor communities where economic and social amenities are not good. Contrary to its alleged health benefits, cow urine was shown to be highly toxic when it was used for the treatment of convulsion, as it was traditionally claimed in Africa. A report of D.D. Oyebola and R.A. Elegbe from Nigeria in the Transactions of the Royal Society of Tropical Medicine and Hygiene in 1977 revealed that administration of cow urine was associated with severe poisoning, sometimes with a fatal outcome in children. Their experiment in dogs indicated that the urine caused respiratory arrest and irregular blood pressure in dogs. ${ }^{21}$ Two years earlier, they had experimentally confirmed that cow urine was as toxic as nicotine and both caused lethal convulsion in mice. ${ }^{22}$ Similar results on cow urine as poison were subsequently reported. ${ }^{23,24}$ They went on to identify over 50 important chemical compounds, among them is nicotine. ${ }^{25}$ Even with this medical warning, cow urine is still the second-most used therapy for convulsion in Nigerian children. ${ }^{26}$

What is good for the gander, say Indians, is not for the goose, say Africans. While it may be wise to conjecture that Nigerian cow urine is dangerous (to say that because it is not a Hindu cow would falsify the purpose), and that of the Indian cow is healthy, the true picture is not. Very sane Indian ophthalmologists reported that that eye injury (ocular surface injury) in some cases is due to application of cow urine as prescribed by traditional healers. Reporting in 2017, they elaborately condemned such quackery for its dangerous effects. ${ }^{27}$

\section{Other Bullshit in the Name of the Holy Cow}

On 25 April 2017, the Science for Equity, Empowerment and Development (SEED) division of the Department of Science and Technology (DST) issued an office memorandum to constitute a National Steering Committee for Scientific 
Validation and Research on Panchagavya (SVAROP). It was initiated by the DST, the Department of Biotechnology (DBT) and the Council of Scientific and Industrial Research (CSIR), in collaboration with IIT-Delhi. The committee is being chaired by Harsh Vardhan, and co-chaired by Vijay P. Bhatkar, who is the Chancellor of Nalanda University, as well as the national president of Vijnana Bharati, an NGO linked to RSS. Panchagavya is the most important of all the various medical preparations made from cow's excretions. It is a mixture of five (panch) products of the cow (gavya): milk, curd, ghee, dung, and urine. The programme will cover "scientific validation of panchagauya for medicines and health, scientific validation of and its products for agriculture applications, for food and nutrition. ${ }^{28}$ Milk and its products are alright, but a cow dung in medicine is just bullshit. Their scientific outlook is stooping at the level of a Bos taurus bottom.

If Christian and Jews tell that Balaam's ass (not his excretory platform, but a donkey) could talk, why would we discredit an oxygenexhaling cow. Vasudev Devnani, a qualified engineer and Minister of Education and Panchayati Raj in Rajasthan, claimed that the cow is the only animal that inhales and exhales oxygen. Speaking at the Hingonia Cow Rehabilitation Centre, Devnani also said that diseases such as cold and cough are healed if one goes near a cow and emphasised on the role of youth in promoting cow conservation in the entire country. He also claimed that cow dung has ample quantity of vitamin $B$ that results in soaking radioactivity. ${ }^{29}$ As providence would have it, a discussion in Rajya Sabha session in March 2017 revolved around cow. Basavaraj Patil, BJP MP from Karnataka, said, "Ghee made of cow's milk has up to 47 per cent oxygen. Cow is the only animal which takes oxygen and gives back oxygen." He claimed that if a cow carcass is buried, its "chemical action" is worth fertilizer amounting to Rs. 8,000. Meghraj Jain, another BJP member claimed that an experiment at Mumbai's Tata Cancer Hospital proved that haemoglobin level of cancer patients remained stable even after chemotherapy when cow urine was used. ${ }^{30}$
For the utter disenchantment of this BJP bull science, the United Nations Food and Agriculture Organization reported in 2006 that increased cattle farming due to increased demand of beef and milk products is a menace to pollution of various kinds. When emissions from land use and land use change are included, the livestock sector accounts for $9 \%$ of $\mathrm{CO}_{2}$ deriving from human-related activities and produces a much larger share of even more harmful greenhouse gases. Cattle farming generates $65 \%$ of human-related nitrous oxide, which has 296 times the Global Warming Potential (GWP) of $\mathrm{CO}_{2}$. And it accounts for respectively $37 \%$ of all human-induced methane (23 times as warming as $\mathrm{CO}_{2}$ ), which is largely produced by the digestive system of ruminants, and $64 \%$ of ammonia, which contributes significantly to acid rain. ${ }^{31}$

The report further suggests that "The environmental costs per unit of livestock production must be cut by one half, just to avoid the level of damage worsening beyond its present level." Most of this comes from manure. BJP sympathizers cannot be excused for their flagrant disregard to the biological and environmental facts.

News abound, BJP followers have massacred people in their neurotic veneration of cow. For them the enduring commandment is: Thou shalt not eat beef, or else you die. These acts of fanaticism are not beefing up science and secularism.

\section{The Indian (Science Congress) circus}

One of the most deplorable events in Indian science, the $102^{\text {nd }}$ Indian Science Congress, held in January 2015 in Mumbai, was remembered as some kind of pseudoscientific convention, and ended up only in controversies on the dignity and credibility of some Indian scientists.

The session titled "Ancient sciences through Sanskrit" was at the outset deceptively unscientific. Speakers talked of a Hindu sage inventing interplanetary spacecraft 7,000 years ago, a herbal paste applied to a person's feet for dowsing (locating underground water), and bacteria in cows turning any material into gold. A retired pilot trainer Anand Bodas presented that official history only noted the Wright Brothers as the 
first to fly in plane in 1903, but the inventor of the airplane was really a sage named Bharadwaja, who lived around 7,000 years ago. "The Maharishi," he said, "defined an aeroplane as "a vehicle which travels through air from one country to other, from one continent to other, from one planet to other." He said, "The basic structure was of 60 by 60 feet and in some cases, over 200 feet," which was driven by "40 small engines". ${ }^{32}$ The source of Bodas' science was the Vaimanika Shastra, which fortunately was dated by a team from the Indian Institute of Science in Bengaluru as a very modern literature, hardly a century old at most. The teams clarified that the flying machines described in the text were "poor concoctions" and "unimaginably horrendous." In December 2015, California-based Indian scientist Ramprasad Gandhiraman began a petition to Indian Science Congress "to stop providing a platform for pseudoscience." More than 200 Indian scientists have signed the petition since then. ${ }^{33}$

An Indian-born British Nobel laureate, and President of the Royal Society, Sir Venkatraman Ramakrishnan was invited to deliver a Har Gobind Khorana lecture at the Indian Science Congress 2016. Asked of his experience, he remarked that "very little science was discussed. It was a circus." And made a vow, saying, "I will never attend a science congress again in my life." (See Lalchhandama, 2016.34) Speaking at the new headquarters of the Medical Research Council's Laboratory of Molecular Biology at Cambridge in 2017, Ramakrishnan expressed his concern with India, and said, "All this sectarian squabble about who eats what kind of meat and all this religious antagonism between different groups is harmful to the country," alluding to beef ban, and added, "unless India invests in innovation, science and technology, it's going to lose the race." 35

\section{The Bos with a golden pee}

As if to prove the Indian Science Congress remark on the ability of cows to produce gold, an instance of extreme obsession with cow urine transpired in Gujarat. Gujarat, as is clear, is the stronghold of BJP where Modi himself reigned as Chief Minister for a record-setting twelve-andhalf year before taking the reign of Prime Minister of India. In June 2016, the Junagadh Agricultural University (JAU) in Gujarat announced the discovery of gold in the urine of Gir cows. Using gas chromatography-mass spectrometry a JAU research team led by B.A. Golakia, Head of Biotechnology Department, analysed urine samples of 400 Gir cows showed traces of gold ranging from 3-10 mg from one litre urine. JAU research was apparently inspired by the Vedic literature, as Golakia said, "Till now, we have heard about presence of gold in cow urine from our ancient scriptures and its medicinal properties. Since there was no detailed scientific analysis to prove this, we decided to undertake a research on cow urine." ${ }^{36}$ Let's dig this bogus gold mine up.

What is otherwise known as genuine science tells us that heavy metals are created in dying stars-not celebs, but celestial bodies. For a long time, it was generally accepted that heavy elements such as gold are synthesised from iron in the superhot and gigantic explosion of supernovae. But in 2016, a tiny, faint galaxy, a satellite of the Milky Way called Reticulum II (Ret II) indicated that elements such as gold and platinum could be synthesised by merger of neutron stars. The Laser Interferometer Gravitational Wave Observatory (LIGO) and Virgo interferometer measurements of gravitational waves of a neutron star GW170817 merger further evidenced this process. ${ }^{37}$ These elements were brought into Earth by lucky coincidences from asteroids impacts about 3.4 billion years ago. ${ }^{38}$ The asteroid that formed Vredefort Crater 2 billion years ago is possibly what made the Witwatersrand basin the richest gold deposits on earth. The South Africans should be grateful for that.

People of scientific persuasion from antiquity to $17^{\text {th }}$ century were busy as a bee trying convert base metal such as lead into noble metals such as gold and silver, calling it transmutation. The failure in epic proportion of what was later called alchemy gave birth to practical chemistry. The birth of chemistry did not solve the problem either. It took a Japanese team of physicists led by Hantaro Nagaoka, at the Tokyo Imperial Uni- 
versity, to first synthesis gold from mercury in 1924 by neutron bombardment using highcurrent electric discharges. To add to the alchemist's nightmare, lead is formed from gold in the stellar nuclear fusion. But chemical synthesis such as this is of no practical commercial value, because they are not in lumps or bars, but only at minuscule level detectable with sophisticated detectors. If we take the JAU discovery at face value, as Shrihari Achayath humorously calculated, ${ }^{39}$ an average Gir cow can will produce about $23 \mathrm{~g}$ of gold in a year. Supposing the gold is $24 \mathrm{k}$, by today's rate, it will be worth $\$ 1310.80$ (Rs. 85436)-and that is from one cow only. What a surplus for the biogas and milk. Cattle farming should be a new Gold Rush. But, in reality, synthesis of gold would be so expensive that one would require a particle accelerator (CERN was selling a small one at $\$ 2$ billion), and a patience to wait a few thousands or even million years to obtain a sizable particle.

\section{The moral of the peacock story - celibacy with beauty}

India is blessed with its majestic peafowl (Pavo cristatus) as a national bird, even the most human-made objects in their splendour would not match their true colour-rich plumage. Justice Mahesh Chandra Sharma, on his parting day of Rajasthan High Court in June 2017, the day the High Court decreed life imprisonment for cow slaughter, publicly demanded cows be declared national animals. It would have been quite acceptable, had he not gone further to explain the sanctity of cow in terms peafowl, and was quoted as saying, "Peacock is a brahmachari [celibate] and it does not have sex with a female peacock. The peahen gets pregnant drinking the tears of the peacock. Even Lord Krishna carried the feather of a peacock on his head."40 Espousing Vasudev Devnani's outrageous concept that cow exhale and inhale oxygen, he added that a cow is a mobile clinic or a hospital on its own, and that cow urine had "miraculous properties of destroying germs and preventing ageing." Given the health benefits of milk, it is an overstatement to say that it prevents cancer from entering the blood cells, mooing of cow kills the pathogens in the air, cow dung kills cholera germs; and it definitely is farfetched to say that cow, through its horns, absorbs "cosmic" energy. ${ }^{42}$ (For a critical examination of Sharma's claims, see Mazoomdaar, 2017.43)

The fact of the matter is that peafowl reproduce sexually as any other birds, with characteristic courting, mating and intercourse behaviours. Only males are elaborately ornamented with colourful plumage, endowed with a flashy and bulky train (their tail is called). It was these biological features that piqued the curiosity of Charles Darwin. What Darwin realised was that such excessive endowment could have no survival benefits, because it would render the peacock handicap for escaping predators or for foraging - the very antithesis of his brain-child theory, natural selection. But he hypothesised, writing in The Descent of Man, that the cost-benefit is on sex choice by peahen-peahen tend to choose peacock with the most perfect plumage and train:

\begin{abstract}
Are we not justified in believing that the female exerts a choice, and that she receives the addresses of the male who pleases her most? It is not probable that she consciously deliberates; but she is most excited or attracted by the most beautiful, or melodious, or gallant males. Nor need it be supposed that the female studies each stripe or spot of colour; that the peahen, for instance, admires each detail in the gorgeous train of the peacock-she is probably struck only by the general effect. ${ }^{44}$
\end{abstract}

This sexual selection theory, and its ally the handicap principle, has been experimentally proven in the most beautiful ways in peafowl. ${ }^{45}$ The otherwise cumbersome and exaggerated ornamentation in a peacock is the key to success mating. Female choice is a major driving factor in evolution of sex-related behaviour. ${ }^{46-48}$ Scientific experiments on peafowl after Darwin have convincingly shown that beauty is not just to the eye of the beholder, or just a skin deep, it is one of the indispensable tools of natural selection (operating on sex choice) in animals. 
In some sense the remorseful hilarity in Sharma's faith is enough to make anybody to laugh until one cries to tears-but then that could make some women pregnant. Peafowl brings India to fame in science, but Sharma smashed it down to shame.

\section{Doomed Darwinism}

As evidently the most abused and misunderstood concept, Darwinian thinking has triumphed in science and dominated the entire realm of biology, but it met one of its most recent formidable nemesis in India. Calling himself "a man of science", for he is a graduate in chemistry, had served as an Indian Police Service officer, Satyapal Singh, Minister of State for Human Resources Development (HRD), said one of the most damning remarks about evolutionary biology. Speaking at the All India Vaidik Sammelan, he asserted, "Darwin's theory (of evolution of man) is scientifically wrong. It needs to change in school and college curriculum. Since the man is seen on Earth he has always been a man." He added, "Nobody, including our ancestors, in written or oral, have said they saw an ape turning into a man. No books we have read or the tales told to us by our grandparents had such a mention," He extended his remarks that there should be a debate over this in an international conference, organised presumably by the HRD Ministry, to prove Darwin. ${ }^{49}$ In his defence, one might expect such remarks to be Freudian slip blurted out in the heat of a moment, but it was not. At later public speech in Assam, he concurred, "I have a list of around 10 to 15 great scientists of the world who have said there is no evidence to prove that the theory of evolution is correct," adding that Albert Einstein had agreed the theory was "unscientific". ${ }^{50}$

We have had a more than itching experience of Creation Science and its vociferous offspring Intelligent Design in America in the last century. A century of absence of evidence for these antievolutionists' claim is enough to convince, or at least impress, any rational person that alternative views are not worth looking. Dissenting proclamations such as Singh's are not going to fare any better.

\section{Defending Darwin}

Gifted with an ingenious power of prediction, Charles Darwin had vouched for his theory of natural selection against doubters and future critiques, saying, "He who rejects these views on the nature of the geological record, will rightly reject my whole theory. For he may ask in vain where are the numberless transitional links which must formerly have connected the closely allied or representative species, found in the several stages of the same great formation." 51

Mahatma Gandhi had a good perception of Darwinian theory. One may note the striking parallelism of his moral law with that of Darwinian principle, when he stated: There is no reason to believe that there is one law for families and another for the nations. History, then is, a record of an interruption of the course of nature. Soul-force, being natural, is not noted in history. ${ }^{52}$ And speaking directly on Darwin's theory, he once wrote, "Darwin for the greater part of his book Origin of the Species [sic] has simply massed fact upon fact without any theorising, and only towards the end has formulated his conclusion which, because of the sheer weight of testimony behind it, becomes almost irresistible. Yes I have criticised even Darwin's generalisation as being unwarranted. A proposition must not only be able to satisfy the analytical test, but must also be proved conversely by synthesis before its universal validity can be established..$^{53}$

Nehru wrote a letter in 1933 to her then 16year-old home-taught daughter Indira Gandhi, in which he exclaimed, "Darwin's book [On the Origin of Species by Means of Natural Selection] was epoch making; it produced a vast impression and helped in changing the social outlook more than any other scientific works. It resulted in a mental earthquake... [A] shaking which wakes us to reality is good. We could of with such a shaking in India! [Because of Darwinian thinking and technological advances] In every direction and in every department of life, science has 
revolutionised the world." ${ }^{54}$ And he continued to appreciate the power of science, and trying to inculcate that outlook in Indira, he said, "[S] cience does answer more and more questions, and helps us to understand life, and thus enables us, if we will but take advantage of it, to live a better life, directed to a purpose worth having. It illuminates the dark corners of life and makes us face reality, instead of the vague confusion of unreason." 55 If I may borrow Charles Dickens' immortal lines (from The Tales of Two Cities), with the BJP, we are running backward to worst of times, the age of foolishness, the epoch of incredulity, the season of Darkness, the winter of despair, and all in the wrong direction. These BJP sentiments are at best grotesque departure from Nehru's scientific temper, a disheartening detour from the good shaking, and at worst downright denigration of the Fundamental Duties.

What our BJP leaders missed is the fact that "there is a fundamental difference between religion, which is based on authority and science, which is based on observation and reason. Science will win, because it works." (Not my words, but Stephen Hawking's on ABC World News on 7 June 2010.) The BJP ideologies were best described by Nehru's remarks: Modern thought attracted them, but they lacked its inner content, the modern social and scientific consciousness. Some tried to cling tenaciously to the dead forms of the past, seeking relief from present misery in them. ${ }^{56}$ They are exactly just that.

For a brilliant satire, an Open Letter to the Minister by Gauhar Raza, whose designation is simply "A scientist corrupted by modern science", is absolutely worth reading for its pun, irony and wit. His closing remark, which I am irresistibly tempted to quote, says, "If the larger world and scientific community laughs at you, if they call you illiterate, ignorant, unscientific, irrational or uncivilised, take no notice. Just crush all sciences under your boot." 57

For those who are deprived of a sense of humour, the joint statement by the three top scientific organisations in India, namely the Indian Academy of Sciences, the Indian National Science Academy and the National Academy of
Sciences, announced on 22 January 2018 is laudable. It states: ${ }^{58}$

\section{Summary}

It would be a retrograde step to remove the teaching of the theory of evolution from school and college curricula or to dilute this by offering non-scientific explanations or myths.

\section{Article}

The Hon. Minister of State for Human Resource Development, Shri Satyapal Singh has been quoted as saying that "Nobody, including our ancestors, in writing or orally, have said they saw an ape turning into a man. Darwin's theory (of evolution of humans) is scientifically wrong. It needs to change in school and college curricula."

The three Science Academies of India wish to state that there is no scientific basis for the Minister's statements. Evolutionary theory, to which Darwin made seminal contributions, is well established. There is no scientific dispute about the basic facts of evolution. This is a scientific theory, and one that has made many predictions that have been repeatedly confirmed by experiments and observation. An important insight from evolutionary theory is that all life forms on this planet, including humans and the other apes have evolved from one or a few common ancestral progenitors.

It would be a retrograde step to remove the teaching of the theory of evolution from school and college curricula or to dilute this by offering non-scientific explanations or myths.

The theory of evolution by natural selection as propounded by Charles Darwin and developed and extended subsequently has had a major influence on modern biology and medicine, and indeed all of modern science. It is widely supported across the world.

See for example http://www.nas.edu/evolution/ TheoryOrFact.html. 


\section{References}

I. Nehru, J. (1946 [1989]). The Discovery of India (Centenary Edition). Oxford (UK): Oxford University Press. p. 23.

2. Nehru, J. Ibid. p. IO2-I03.

3. Nehru, J. Ibid. p. 409.

4. Nehru, J. Ibid. p. 512.

5. Ambedkar, B.R. (1950). Buddha and the future of his religion. Maba-Bodbi Journal. 58: 199-206.

6. Rahman, M. (20I4). Indian prime minister claims genetic science existed in ancient times. The Guardian.

7. Tharoor, S (2017). India's War on Science. Project Syndicate.

8. Crasta, R (20I7). Save Our Science: BJP is taking India's scientific standing to an all-time low. Catch News.

9. VIBHA (20I7). AIMS \& Objectives. Vijnana Bharati.

Io. Gandhi, J. (2015). An uncertain glory. The Hindu.

II. Heisenberg, W. (1927). Über den anschaulichen Inhalt der quantentheoretischen Kinematik und Mechanik. Zeitschrift für Physik. 43: 172.

I2. Kumar, P (2017). Govt shelves Ramdev's Vedic Education Board proposal. Deccan Herald. Retrieved is March 2018.

13. Aggarwal, Y. (2018). RSS agenda: Replacing science with myths. Deccan Chronicle. Retrieved 19 March 2018.

I4. PTI (2016). Yagya' brings rain, produces 300\% more oxygen: BJP MP in Lok Sabha. Hindustan Times.

I5. PTI (2018). India's science minister claims Stephen Hawking had said Vedic theory was superior to $\mathrm{E}=\mathrm{mc2}$. The Telegraph.

16. Mudur, G.S.; Roy, A. (2018). Trustee's rebuttal Minister's claim on Hawking. The Telegraph.

17. Mohanty, I.; Senapati, M. R.; Jena, D.; Palai, S. (20I4). Diversified uses of cow urine. International Journal of Pharmacy and Pharmaceutical Sciences. 6: 20-2.

18. Dhama, K.; Chauhan, R.S.; Singhal, L. (2005). Anticancer activity of cow urine: Current status and future directions. International Journal of Cow Science. I: I-25.

19. Jain, N.K.; Gupta, V.B.; Garg, R.; Silawat, N. (2010). Efficacy of cow urine therapy on various cancer patients in Mandsaur District, India - A survey. International Journal of Green Pharmacy. 4: 29-35.

20. Loeffler, JM (2010). The golden fountain-is urine the miracle drug no one told you about? The Pan African Medical Journal. 5: 13.

2I. Elegbe, R.A.; Oyebola, D.D. (1977). Cow's urine poisoning in Nigeria: cardiorespiratory effects of cow's urine in dogs. Transactions of the Royal Society of Tropical Medicine and Hygiene. 71: 127-132.

22. Oyebola, D.D.; Elegbe, R.A. (1975). Cow's urine poisoning in Nigeria experimental observations in mice. Tropical and Geographical Medicine. 27: 194-202.

23. Oyekan, A.O.; Laniyonu, A.A. (1984). Studies on the contributive effects of the different constituents of cow's urine concoction in rats (Part I). Tropical and Geographical Medicine. 36: 193-199.

24. Oyekan, AO; Laniyonu, AA (1984). Studies on the contributive effects of the different constituents of cow's urine concoction in rats (Part II). Tropical and Geographical Medicine. 36: 20I-6.

25. Oyebola, D.D. (1983). Cow's urine concoction: its chemical composition, pharmacological actions and mode of lethality. African Journal of Medicine and Medical Sciences. 12: 57-63.

26. Anigilaje, E.A.; Anigilaje, O.O. (2012). Childhood convulsion: inquiry about the concerns and home management among mothers in Tegbesun, a Periurban Community in Ilorin, Nigeria. ISRN Pediatrics. 2012: 209609.

27. Khanduja, S.; Jain, P.; Sachdeva, S.; Phogat, J. (2017). Cow urine keratopathy: A case report. Journal of Clinical and Diagnostic Research. n: NDo3-NDo4.

28. PTI (2017). Union Science and Technology Minister to head panchgavya panel with RSS, VHP members. The Hindu.

29. Khan, S. (2017). Cows inhale, exhale oxygen, says Rajasthan education minister Vasudev Devnani. The Times of India.

30. Mishra, A. (2017). Cow, its urine and dung on Rajya Sabha discussion menu. The Indian Express.

31. Steinfield, H.; Gerber, P.; Wassenaar, T.; Castel, V.; Rosales, M.; de Haan, C. (2006). Livestock's Long Shadow: Environmental Issues and Options. Rome: Food and Agriculture Organization of the United Nations. pp. xxi, 79-I22.

32. Deshpande, V. (2015). 'Rishi has given guidelines to make planes'. The Hindu.

33. Subramanian, S. (2015). Hindu nationalists claim ancient sage 'invented spaceships'. The National.

34. Lalchhandama, K. (2016). Our progress in the practice of science - not much. Science Vision. 16: I5I-I54.

35. Roy, A. (2017). Focus on education, not meat: Laureate. The Telegraph.

36. Parmar, V. (2016). Holy cow! Junagadh Agricultural University scientists find gold in Gir cow urine. India Today. 
37. Frebel, A; Beers, T.C. (2018). The formation of the heaviest elements. Physics Today. 71: 30-37.

38. Willbold, M.; Elliott, T.; Moorbath, S. (2oII). The tungsten isotopic composition of the Earth's mantle before the terminal bombardment. Nature. 477: 195-198.

39. Achayath, $\mathrm{S}$. Is the article about gold in cow urine true? Quora.

40. Anon (2017). Rajasthan High Court judge says peacocks don't have sex: How do you think peacocks reproduce? India Today.

4I. Bedi, R. (2017). Indian judge claims peacocks reproduce from tears and that cow urine prevents ageing. The Telegraph.

42. Anon (2017). Cows exhale oxygen, absorb cosmic energy, home to gods: Rajasthan HC judge. Hindustan Times.

43. Mazoomdaar, J. (2017). A little fact-check of Honourable Judge's cow order in Rajasthan. The Indian Express.

44. Darwin, C. (1871). The Descent of Man and Selection in Relation to Sex (Vol. II). London (UK): John Murray. p. 123.

45. Johnstone, R.A. (1995). Sexual selection, honest advertisement and the handicap principle: reviewing the evidence. Biological Reviews. 70: I-65.

46. Petrie, M.; Williams, A. (22 February 1993). Peahens lay more eggs for peacocks with larger trains. Proceedings of the Royal Society B: Biological Sciences. 251: 127-I3I.
47. Petrie, M.; Tim, H.; Carolyn, S. (I99I). Peahens prefer peacocks with elaborate trains. Animal Behaviour. 4I: 323-33I.

48. Dakin, R.; Montgomerie, R. (2014). Conditiondependent mate assessment and choice by peahens: implications for sexual selection. Behavioral Ecology. 25: IO97-IIO4.

49. Bagla, P. (2018). India's education minister assails evolutionary theory, calls for curricula overhaul. Science. Online. doi:Io.II26/science.aato816.

50. Safi, M. (2018). Indian education minister dismisses theory of evolution. The Guardian.

5I. Darwin, C. (I859). On the Origin of Species. London (UK): John Murray. p. 342.

52. Sharma, N. (2008). Makiguchi and Gandhi Their Education Relevance for the 2Ist Century. Lanham (US): University Press of America. p. 64.

53. Gandhi, M. (1945). Generalisation [Quoted from Harijan, 6/7/1940]. In Chander, J.P. Teachings of Mahatma Gandhi. Lahore (India): Indian Printing Works. pp. 243 -244 .

54. Nehru, J. (1934). Glimpses of World History Vol. II. Allahabad: Kitabistan. pp. 814-82I.

55. Nehru, J. (1934). Ibid. p. 1362.

56. Nehru, J. (1934). Ibid. p. 357-358.

57. Raza, G. (2018). Open Letter to the Minister for Demolishing Theory of Evolution. National Herald.

58. Team Confluence (2018). Joint Statement by the Three Science Academies of India. Indian Academy of Sciences. 